Theatre Research in Canada

Recherches théâtrales au Canada

\title{
Accuracy and Ethics, Feelings and Failures: Youth Experimenting with Documentary Practices of Performing Reality
}

\author{
Kathleen Gallagher, Scott Mealey and Kelsey Jacobson
}

Volume 39, Number 1, 2018

URI: https://id.erudit.org/iderudit/1055468ar

DOI: https://doi.org/10.7202/1055468ar

See table of contents

Publisher(s)

Graduate Centre for the Study of Drama, University of Toronto

ISSN

1196-1198 (print)

1913-9101 (digital)

Explore this journal

Cite this article

Gallagher, K., Mealey, S. \& Jacobson, K. (2018). Accuracy and Ethics, Feelings and Failures: Youth Experimenting with Documentary Practices of Performing Reality. Theatre Research in Canada / Recherches théâtrales au Canada, 39(1). https://doi.org/10.7202/1055468ar

\section{Article abstract}

For young artists and their educators, the adoption of documentary theatre practices can be deeply appealing given their seemingly privileged capacity to truthfully represent the multi-faceted realities of contemporary life. The often ubiquitous impulse, however, toward straightforward, narrative representations may in fact betray the reality (felt and lived) that young people seek to earnestly convey. This article, drawing on three different examples of youth engagement with documentary and oral history theatre techniques in the cities of Toronto (Canada) and Tainan (Taiwan), explores how young theatre-makers find themselves wrestling with the ethics of unsettling and/or reinforcing the performance and reception of real stories in "the right way." The authors conclude by advocating for an uncynical praxis of failure that resists well-intentioned, normative performances of past "truths" and makes instead disruptive and often messy space for socio-political, pedagogical, and aesthetic possibilities.
All Rights Reserved (C) Theatre Research in Canada / Recherches théâtrales au Canada, 2018
This document is protected by copyright law. Use of the services of Érudit (including reproduction) is subject to its terms and conditions, which can be viewed online.

https://apropos.erudit.org/en/users/policy-on-use/ 


\title{
Accuracy and Ethics, Feelings and Failures: Youth Experimenting with Documentary Practices of Performing Reality
}

\author{
KATHLEEN GALLAGHER, SCOTT MEALEY, AND KELSEY JACOBSON
}

\begin{abstract}
For young artists and their educators, the adoption of documentary theatre practices can be deeply appealing given their seemingly privileged capacity to truthfully represent the multi-faceted realities of contemporary life. The often ubiquitous impulse, however, toward straightforward, narrative representations may in fact betray the reality (felt and lived) that young people seek to earnestly convey. This article, drawing on three different examples of youth engagement with documentary and oral history theatre techniques in the cities of Toronto (Canada) and Tainan (Taiwan), explores how young theatre-makers find themselves wrestling with the ethics of unsettling and/or reinforcing the performance and reception of real stories in "the right way." The authors conclude by advocating for an uncynical praxis of failure that resists well-intentioned, normative performances of past "truths" and makes instead disruptive and often messy space for socio-political, pedagogical, and aesthetic possibilities.
\end{abstract}

Aux yeux des jeunes artistes et de ceux qui les forment, l'adoption de pratiques documentaires en théâtre peut être très attrayante étant donné leur aptitude apparente à représenter fidèlement les réalités complexes de la vie contemporaine. Or, le reflexe souvent omniprésent d'offrir de franches représentations narratives peut dans les faits trahir la réalité (sentie et vécue) que les jeunes cherchent à transmettre. Dans cet article, Gallagher, Mealey et Jacobson partent de trois exemples d'expériences vécues par des jeunes à Toronto (Canada) et à Tainan (Taïwan) où, devant des techniques théâtrales relevant du documentaire et de l'histoire orale, les jeunes participants ont eu à lutter avec des questions morales liées à la décision de "bien » troubler ou renforcer la performance et la réception d'histoires vraies. Les auteurs terminent en préconisent une pratique non-cyclique de l'échec qui résiste aux représentations bien intentionnées mais normatives des "vérités » du passé et qui permet de créer un espace déstabilisant et souvent chaotique pour explorer des possibilités sociopolitiques, pédagogiques et esthétiques.

[F]ocusing on children - not as future adults but as people worthy of study in their own right-decenters the autonomous adult as the normative subject of humanistic inquiry and pushes us to validate dependence, imperfection, and malleability as fundamental to the human condition more broadly. (Field 270)

This article considers the artistic and social processes and effects of youth theatre-making 
when it is attuned to documenting reality. The work to be examined comes from a global, multi-sited ethnographic research project, Youth, Theatre, Radical Hope and the Ethical Imaginary: An Intercultural Investigation of Drama Pedagogy, Performance, and Civic Engagement (SSHRC-funded 20I4-2019), which uses a socially-engaged and collaborative model of research to ask what makes the classroom/theatre workshop a forum for the creative exploration of civic engagement-who am I, relative to others, and what compels me to act upon my world. Working with particular models of theatre-making committed to "the dynamics of the actuality" (Paget 317) in each of the first three years of the five-year study, we and our research collaborators have been especially interested in what might be learned about selfother relations and what kinds of ethical and pedagogical spaces are being cultivated through documentary theatre-making practices.

In the first three years of the study, each of our research sites (which comprise high school, university, and community-based theatre-making spaces in Toronto (Canada), Lucknow (India), Tainan (Taiwan), Coventry (England), and Athens (Greece)) have worked with Verbatim, Oral History Performance, and Devising practices. ${ }^{I}$ In the following analysis we offer three accounts of these practices, two of which are drawn from grade $\mathrm{II} / \mathbf{1} 2$ classes in the Toronto high school, Regal Heights, while the third will come from our fieldwork in our Tainan site, in a theatre studies department with first and second year undergraduate students at the National University of Tainan. ${ }^{2}$

The first section of the article focuses on the verbatim practice carried out in Year One of the study in the Toronto high school grade 12 drama classroom (seventeen to eighteen year olds), where we spent sixteen weeks in 20I4. The second section centres on the oral history performance practice carried out in Year Two of our study in the Toronto high school grade II/I2 (sixteen to eighteen year olds) drama classroom, where we spent sixteen weeks in 2015 . The final section centres on the verbatim and oral history practices carried out in our Tainan university classes (eighteen to twenty year-olds), where we spent ten days in November 2016, in addition to our correspondence via a digital communications platform where we share performance data and further our research with our international collaborators. All three sections feature young performers wrestling with a deep desire to represent the reality they have encountered in the pedagogical environment accurately and ethically, but also to make space for their feelings about those realities. It has been very much in keeping with documentary traditions that privilege direct (or near direct) engagement by the scribe/performers with typically unheard or underrepresented speakers, followed by performances that credibly reflect the vernaculars and actualities of the original encounter (Anderson and Wilkinson; Haley; Paget). The first example draws from a documentary practice in which young performers are struggling to depict the callous murder of a young black man and find a way forward that values their feelings about the case in question, despite the barrenness of the "facts" they were working from. Our second example illustrates the perceived failure of a performance for an audience of peers when the young performers find themselves tightly bound to a normative narrative about disability that failed to effectively capture the nuance of the story being represented. Here, they felt called to "teach" their audience and to ethically represent the narrative. Our last example illustrates a fear felt by the young creators in all of our examples: the overwhelming desire to "get it right," even "correcting" the truth by deviating from the actual "coming out" story shared by a student. The students in fact altered 
the ending to have the gay character commit suicide in order to forcefully alert the audience to the potential consequences of homophobia. Their desire to "teach" an anti-homophobia lesson to their audiences gave them licence, they felt, to make the story even more distressing, as an act of advocacy of sorts. In all three examples then, the students contend with competing notions of representation, feelings, and failure as very real complications of documentary theatre-making.

While the convergence of theatre and reality matters to the quotidian existence of often marginalized youth (Gallagher, "Why Theatre Matters"), there is, as many are discovering, an increasingly urgent caveat. The application of "natural" or "realistic" mimetic performance styles - still a dominant approach in popular western culture and classrooms (Barker 291; O'Toole 485) - to documentary forms of theatre (and valorized in the work of artists like Anna Deavere Smith), falls short, we have observed, for young people who are navigating an increasingly fragmented and destabilized world. We have found this to be the case despite documentary and verbatim theatre's seemingly well-intended aim of accurately depicting diverse, narrative "truths in a simple and accessible way" (Anderson and Wilkinson 157). We wonder, instead, following Field as quoted at the beginning of this article, would youth be better served by theatrical practices that embrace imperfection, malleability and relational dependence? And how might such frames clarify the often fragmentary, disruptive, partial, and yet frequently perceptually true "reals" that young people draw from in their attempts at respectful truth-telling of so-called real life? This article offers a critical evaluation of how contemporary youth earnestly engage in documentary practices, looking particularly at three examples where different students wrestled with received social memory, the affective real (feeling-knowing), and the implications of failure. By engaging in analysis of this sort, we are acknowledging that, while youth may not always be equipped with the capacity for high-level theatrical production, they are nevertheless engaged in important aesthetic and socio-political thinking. We feel such thinking is worth our critical engagement, not only for the sake of its application to the lives of young drama students, but also because of its potential for disrupting the "real" normativities featured in theatre by/for adults. As our article will further illustrate, the performances that are devised and shared by young people do not always best represent the depth of social and artistic learning that may have been experienced in the devising process. And this recognizable reality deserves further pedagogical reflection.

There are several convergent points about documentary theatre-making practices that will be exemplified through our empirical data (interviews and observations) in each of the sites. Across the three sections, we will illustrate especially: the power of affective investment in documentary theatre practices; the precarious balance between the performance of care for the real and the reproduction of the real itself; the imperative to command the attention of, and educate, an audience; and the pull of the narrative real versus the invocations of the real through partial or disrupted gestures or enactments of the real. Taken together, the three sections offer examples of aesthetic, educational, and social success and failure, as young people navigate the challenge of representing a "true story" as well as their feelings about that true story. In our experience, documentary performance work rarely succeeds resoundingly on all of these levels, but much can be reaped, as we will conclude, from a thoughtful engagement with pedagogical and artistic failure. 


\section{Section 1. An Indeterminate Haunting: Dispensing and Disturbing the Painfully Real in Youth-Produced Drama}

\section{Toronto high school students working with verbatim theatre}

Witnessing the seventy-six-second video of the 2015 shooting of Eric Harris feels like watching a ghost story. It opens in the coffin-like interior of a darkened sedan and ends with Harris, pinned by two faceless police officers, uttering his alleged final words: "Oh my God. My breath." It is a minute of murky context, fragmented sensory montage, shifting expressionistic framing, and, most critically, the brutal, untimely death of a man of colour. It also seems, like so many ghost stories, to be a Sisyphean performance, endlessly stuck on repeat, where brief splinters of victims like Harris are condemned to a determined digital eternity. 3

Soon after this video was released, a handful of Toronto drama students were tasked with adapting third-person newspaper (and later video) accounts of the shooting into a short, theatrical docudrama, in the context of their unit on verbatim theatre. It began as a rather innocuous assignment prescribed by the curriculum: select a real story, documented in multiple newspapers, and then "dramatize" it. But, after selecting the option of the slaying of Harris and subsequently watching the video at the request of a supply teacher, they soon found themselves producing their own version of a ghost story. In Western literature, ghost stories are tales of the returning dead, who are either bound to reveal fixed truths or, alternatively, possess the power and will to disturb and challenge "prevailing forces" (Oxford Companion ). While presumably unaware of this tradition, the students, as emerging cultural producers, were still faced with a similar choice: in light of the death to which they were made witness, what kind of ghost would they stage? Should they mount a fact-based, traditionally arced, naturalistic re-enactment of the death they had witnessed-a strongly implied goal of the assignment? Or should they risk the potential failure of ignoring the real instructions in order to take small steps toward redeeming this tragic encounter? Could they stage instead an unsettling and un-real disruption of the "just another [black] name on the list" narrative by depicting indefinite historical happenings interwoven with their own editorializing response (Performance Script 20 April 2015)? We will be suggesting that despite the powerful, safer urge to adopt the former, their need to honour their own feelings of personal disturbance led them to adopt the latter. Consequently, they found themselves creating a theatrical space that was thoughtfully haunted by indetermination and failures.

Official statements made by Tulsa police investigators suggested the death of Eric Harris was also a consequence of a kind of real-life, internal haunting. The deputy drew and fired his revolver, rather than his taser, because at the moment of crisis his capacity to freely respond to present reality had "slipped" when confronted with the more powerful, automatic impulse from his past (Jones). This phenomenon is remarkably similar to the phantasmal process penned by Henri Bergson in Matter and Memory at the dawn of the twentieth century. The philosopher invited his readers to conceptualize their memories as potent ghosts (I45), which are awakened when we encounter the familiar, and whose voices are so powerful that they can often supplant the reality that resurrects them (33-34). This is the process suggested by the police investigators: the deputy's memories of past dangers awoke and "captured" muscles that had previously responded to similar threats by seizing a gun and not a taser. What is made less apparent in their theory, but lurks ominously in the shadows, is that this 
lethal automatic response was initiated by a prone, unarmed man, whose chief danger would seem to be the colour of his skin. He, and a shocking number of other police officers it seems, might be possessed by the reperforming memories of ongoing, naturalized depictions of the iconography of thuggery and "anti-blackness" (Dillon and Page 284). It is such chronic reperformance of past memories that worried Bergson. He bemoaned our tendency to reduce the immediate world around us to fodder for our own inner dialogue, leaving us stuck in a purgatory of individualistic replication (40). Demands for immediate response (such as the perceived, implicit danger of a person of colour) heighten this effect and led to the substitution of mechanical impulses for true seeing (32). Fear of abandoning old realities leaves us blind. It may have been such intensified memories that compelled the other arresting officers to ignore their prisoner's dying pleas, adopting instead a strict adherence to a more familiar text: "Fuck your breath" and "You shouldn't have fucking ran."

For Bergson, relief from this vicious cycle of ghostly retracing requires zones of indetermination, a concept later repopularized by Gilles Deleuze and perhaps echoed in the indictment of historical overdeterminations in the study of blackness (Dillon and Page; Powell). These zones are cognitive states in which decreased demand for certainty and immediacy provide the time and space for expanded perception and independence (Bergson 32, 64-65). It is here, we would suggest, that one can discover a very different performing spirit: the poltergeist. Unlike its perpetual cycling compatriot, the poltergeist is an active, fearless, and spontaneous disruptor of past realties and normative expectations. It engages in the kind of post-structural paralogy invoked by Patti Lather, where destabilizations and indeterminacy oblige the reader (or spectator) to journey through a more complex and imaginative world (678-79). Specifically applied to tragic events such as the Harris shooting, it would seem to invite reimagined documentations of death - Kashif Jerome Powell's "hauntology" - as a form of protest that can make the important performative gesture of re-opening "the dense haunting of blackness" (257). It was this spirit of social memory disturbance which perhaps infected the students tasked with the Harris docudrama, inspiring them to eschew the seemingly natural in favour of a more unknown journey.

In interviews conducted over the short course of their process, students offered words and phrases like "traumatic," "wrong," "infuriating," and "not natural" to describe their reactions to the shooting (Classroom conversation 17 April 2015). We initially assumed they were describing the harm brought on by their encounter with tragic death. However we came to realize they were, instead, expressing their rejection of the mediatized ghost story they were being told. This rejection began with confusion: "Where was the sense," they wondered, "in shooting an unarmed man - taser or not - and then refusing to come to his aid?" (Fieldnotes I5 April 2015). Pressing on they reasoned, "There were so many [other] ways they could have caught him." They eventually came to conclude that, "it's just, it's, I don't know, one of those things that's just not natural" (Classroom conversation I7 April 2015).

While it may be tempting to see this response as naïve and out-of-touch with contemporary realities, it is probably better understood as a radical act of cognitive and social disruption. The virtual signs and representations people gather throughout their lives can, as Bergson contends, easily come to masquerade as normative actuality $(33,37)$. Given enough accumulation, images, even distasteful images such as dying black men, can begin to be received as awful but still natural truths about the world. The students had not yet been paci- 
fied, though. They too acutely felt its "wrongness." This led them to adopt deliberately unnatural, satirical performance choices, reasoning that while one shouldn't "laugh at this type of issue" you can still "exaggerate something that you think is wrong" (Classroom conversation I7 April 2015). At the core of these exaggerations was a disruption of real time. The death of Harris, for instance, was no longer a pinnacle moment but was reordered to take place at the top of the show and then repeated, without fanfare, at the three-quarter mark. Most of the action also took place in the realm of the comically slow, making each choice feel less like a series of causal triggers, and more like a product of absurd self-deceptions. Even their droning use of dispassionate choral elements seemed to mock official narratives as contrived. While not perfectly executed, their choices still cleverly undermined a deterministic paradigm, where horrifying engagements could be excused as unfortunate but inevitable slips. And, as Powell writes, the performance of protest by minoritized people - "a ghost story narrated by muted voices" (254) - must begin with an effort "to re-invent human continuity" (257).

This is not to suggest that the students were fundamentally dispassionate in their performance, it is just that they saved their real emotional investment for super-natural moments. That is, they engaged far more authentically in their Brechtian-esque commentary than in their replications of past action. It was a turn toward an alternative notion of the dramatic that was less about storyboarding the real and more about theatrically extracting the real for instances of personal and social significance (what we later refer to as the human truth rather than the factual truth). The brooding diegetic and earnest narrative juxtaposed with the comic unsettled, but still attracted, the audience. One student, Deen (female, heterosexual, Middle-Eastern, middle class, Muslim), laid out their strategy as follows:

[. . . ] it's about making something dramatic so we can catch people's attention instead of having a documentary about it that nobody's going to watch [...] so [it's] sort of hyping it up a bit, getting people's attention a bit, so they'll pay more attention to it and be like, 'Oh, I didn't know that. I didn't even know that happened.' (Classroom Conversation I7 April 2015)

Deen has an intuitive performer's recognition of the nature of perception that is not unlike that of Gilles Deleuze in Cinema $\mathrm{I}$ : it will always be "minus that which does not interest us" (63). So, she and her classmates sought out ways to "hype" the drama by charging it with social-emotional import that seemed absent in the cold-blooded and often literally faceless accounts in the media. For instance, $M \& M$ (female, African-Canadian, heterosexual, middle class), the production's director, explained that she had "kind of tapped into that hatred I had, like, when I received racist things towards me" as a way of making it relevant for her audience (Individual Interview 29 April 2015). If learning is first dependent on creating a zone to suspend the unthoughtful mind, then for the students it is the power of affective investment, the performance of care for the real and not the real itself, that arrests and demands engagement from its spectators.

There is finally what the students called the "tricky" nature (or perhaps trickster nature) of the source material and its final manifestation. The youth have been typically trained and pushed toward Stanislavskian totalities and they were confounded by the scant context and motivations that had been made available. It seemed to preclude their ability to "be real" because they could not, as instructed, fully "get the character" (Classroom conversation I7 
April 2015). The belief that the degree of knowing is somehow correlated with the ability to evidence real life is belied, however, by Bergson's assertion that true signs or "characteristics of life" are exhibited in their disinclination to be fully settled, to never be fully revealing (64). It was a philosophy the students eventually embraced, visibly staging the limitations of their knowing. For most of the scene, we were allowed to see and hear only slivers of mirrored nature - a gesture, a clipped phrase, a partial description, a simple exchange. Even the most self-evident conclusion was complicated by one of the longest lines in the piece: "You could say he was a victim of police brutality. But does that really count when the white man who shot him was just an unpaid volunteer cop?" (Performance Transcript 29 April 2015). Furthermore, M \& M was very careful to describe their work as a kind of "movement-piece," which she meant as a rebuke to the false certainties that are produced when people "talk too much" (Interview 29 April 2015). M \& M, and the group at large, were advocating for a different kind of representation. One that was a visibly virtual and indirect sign, making no claims on its capacities to demonstrate a narrative real, but nevertheless capable of invoking individual reality with its performance.

Student performances of the dead, their ghost stories, whether on stage or in the mind, are difficult but necessary tests of their relationship with "the real." They tell us something important about their sense of actual power and agency: do people typically earn their death (and life) or has it been imposed upon them? They manifest youth understandings of what it might mean, at the end of one's life, to be seen as a success or a failure. And they reveal how students may contend with recognizing and sharing existential unknowns that are often most apparent when a life has been taken or slipped away. If, as our project contends, we see drama as an environment where care and hope matter, the familiar inclination toward successfully reproducing stories from the past, poignant and/or dramatic as they may be, will inevitably turn as Bergson contends into a petrifying tomb. ${ }^{4}$ It is perhaps the disturbed staging, those hauntings, performatively theorized by these young producers, which are real-y liberating and caring.

\section{Section 2. Following the Feeling-Knowing}

\section{Toronto high school students working with oral history performance}

As in the previous section, a different group of young people in the Toronto classroom in the second year of our study were wrestling with the perceived virtues of what they assumed should be an accurate replication of a "real story" and the feelings they experienced in receiving that story. In this next case, the students were less successful, or rather, found it harder to abandon naturalism and the explicit depiction of "the facts," likely because their source was right there in the classroom with them, a boy who had shared his own personal story through an early exercise in the unit on oral history performance as documentary practice. When these young people say they are privileging the real story, the story that actually happened, they are often, from our observations, privileging their real feelings about the story. A kind of narrative truth is then built from what has been tacitly agreed upon, an experience that, in its attention to feelings and in its totality, makes people feel like they are telling "the true story." In some cases, even, the "facts" can be stretched or manipulated, re-ordered or exaggerated, in order to produce the "real feeling" they are after. The rationale for such a move, however, is often an adherence to the "truth," "how something really happened," as 
they unconsciously elide the account of what they hear (the facts) and replace it with the truth of what they feel. Or, as in the previous example of the Tulsa shooting of Eric Harris, the students used their feelings to intervene upon what they have seen or heard based on their real feelings of disbelief and incredulity.

If this is beginning to sound like Kelly-Anne Conway's "alternative facts" or Donald Trump's Trust me, I know. I've talked to the people. And they've told me, there is good reason for that. The impulse here, as in our Toronto classrooms, is a consequence of what we'll call feeling-knowing, or what experts and the media are now regularly analyzing as Donald Trump's belief in facts as more relevant to his political discourse than actual facts. He wouldn't be the first politician to have contempt for facts that do not align with his political agenda. Fears of psychological disorders aside - narcissism, fascist tendencies, sociopathy - there is a familiar elision at play, one that we saw unfold in the unit on oral history performance at our Toronto research site, with young people in a grade II/I2 drama class. Of course, the consequences for the so-called leader of the free world playing fast and loose with "the truth," or "the truth" being what one believes rather than what one knows to be true based on objective and verifiable facts, is obviously different from young people creating to represent, through theatre, the "true" story of a peer. But, the powerful impulse to create narrative through feeling, and to inspire a particular feeling in an audience, is nonetheless comparable.

In the context of an oral history performance unit in a grade II/I2 drama classroom in our Toronto school, the story to be theatrically re-created was shared by Muckles, who describes himself as male, white, straight, middle class, and Christian. Muckles received a cochlear implant at a very young age, which he had not spoken about with his peers until the moment when he decided to share this story as his offering for his own oral history memory. His group of about twelve students, each of whom shared a personal story from their childhood, decided that Muckles's story would be the one they would work on theatrically to create their oral history performance. It is interesting to note that the two other groups of twelve students each in that classroom chose to create montages of several group members' stories. Though adhering to the "true" stories shared, both of the other groups drew from a wider repertoire of abstract representational practices, while Muckles's group aimed to tell a very naturalistic story, replete with the actual details as remembered and recounted by Muckles. We have argued elsewhere (Gallagher and Jacobson) that this kind of naturalism, coming from a desire to honour the story and get the details right, often fails to communicate the reality in a way that is satisfying to the creators or their audiences.

It was clear early on in their creative process that the young people genuinely felt that they had learned something important about Muckles, and that they had learned also about what it might be like to not hear, and then to suddenly hear. And that, through Muckles, they had also learned something about what it might be like to be a parent of a child with a disability, who then has "corrective surgery" and becomes a member of the hearing world. They used Muckles's detailed account to imagine the joy of his parents. All of this adherence to "the true story" meant that aesthetically and socially this story became a closed meaning system (Aston 37) and a representation fixed upon its didactic imperatives. Barker and Solga have described clearly this kind of phenomenon: "realism" they write, "has come primarily to be defined by political failure, especially in its representations of gender and of queer and minority subjectivities" (3). 
Rather than proceed with an analysis of theatrical realism's well-documented political failures or educational theatre's or youth theatre's well-documented aesthetic and educational failures, instead we would like to consider why the need for a certain narrative truth, a certain feeling-knowing, which itself precluded expressions of complexity and non-normativity, led instead to a pedagogically bereft and aesthetically narrow range of expression that ultimately undermined the efforts of the young actors, despite their high hopes. It must be said at this stage that the classroom teacher's "hands-off" pedagogical style meant that reasonable dramaturgical questions that might have been raised, and indeed were raised by one research assistant in the room, were ignored in favour of the group's declared desire to create it all on their own. This was, in part, because autonomy and self-direction was a very familiar way for these students to work but also, we are arguing, because to have entertained the questions posed or possibilities offered may have led them to doubt comfortable and normative understandings that interrupted their feeling-knowing for the story.

Beth Ferri writes: "To talk of ability is not to speak of a biological 'fact,' but rather to call forth a socially produced system of norms that construct and regulate the boundaries between ability and disability" (29). And more succinctly, Davis concludes: normalcy creates the "problem" of disability. In her reasoning, we begin to see the impulse of Muckles's group and what was at stake socially in their work. Beyond the familiarity with and compulsion to work independently, the students were also the keepers of the unspoken cultural narratives in their deliberations over faithful representation and important artistic messages. Normalcy is not a static category, but rather a social obligation that must be enforced (Davis).

Even more instructive, Ferri further argues that "schools, too, [have] a pivotal role to play in rooting out difference" (32), arguing that within its walls, "normalcy continues to narrow as categories of disability proliferate" (32) which means also that school practices continue to reinforce systemic inequalities in society. But a "realistic" artistic depiction of Muckles's story was imagined to be a supportive and even ethical rendering of a narrative of disability that the group, including Muckles himself, felt was accurate and true. Hearing was the end-goal, the victory, admission into "normalcy" and the entire performance reproduced the joy of ability overcoming disability. Their story re-played how disability is socially, culturally, spatially, temporally, relationally, pedagogically, and artistically normatively located. It was a victory for the feeling-knowing, socially constructed narratives of disability. We are not suggesting that there were not truths revealed in their theatrical story (for example, the joy of parents when their young child turns his head to the sound of his name for the very first time) but the complications of that story, the relationship of the Muckles before surgery to the one after surgery, the ease with which the story of victory reinforces us in our familiar narratives of inequality, remained silenced. Whereas the students and work described in Section I above destabilized the "normalcy" of the real-life event, the students' work here was at pains to reassert the mainstream reading of disability and quiet the complexity, conflict, and paradoxes of the actual story.

Youth studies scholar Andy Furlong makes this distinction about the deaf community in particular: the "small d" deaf community do not associate with other members of the deaf community, strive to identify themselves with hearing people, and regard their hearing loss solely in medical terms. The "Big D' Deaf people identify themselves as culturally deaf, and have a strong deaf identity" (40). We cannot presume to know such details about Muckles 
but it is the case that he was the only deaf person in a class of hearing people. He did confess to enjoying being able to turn his implant off sometimes, returning to his deafness, but that more complicated story did not make it into their performance. They told the story in the most uncomplicated way that assured the felt narrative of triumph over disability. As Scarlett, a group member, described:

It's what captivated me about it, the actual fact that he was deaf and then because of, like, medical advances he was able to hear! For me it was about getting the story across to the audience. (Focus Group Interview I6 December 2015)

Despite our critique here, Muckles, in the end, said he was very happy that he shared his story even though the audience reception of the performance had been disappointing. And it was disappointing because of the care the students had taken with the story they now felt implicated in and responsible for, feeling that it was not being "read" by their audience who laughed inappropriately, not able to feel from the performance itself the social strength of the community that had formed around the story of struggle of one of its members. But it was about his experience of the collective theatre-making that Muckles ultimately spoke most passionately:

I felt there was nothing better to announce my story than this group, uh, last week, right then. Nothing better. They made me comfortable on stage. I felt comfortable because they always had my back. I, I need people who have my back. I don't want people who criticize me; that's one of my pet peeves. I don't want people who criticize me. That's, that's kinda my thing. But they always had my back. That's number one ...And that's why I felt like, "I need to do this story." (Focus Group I6 December 2015)

In Examined Life, Judith Butler in conversation with Sunaura Taylor, who uses a wheelchair because of a congenital physical disability, together think through the distinction between disability and impairment, a discussion very much alive in disability studies. In trying to understand the difference, Butler asks whether disability could be understood as the social organization of impairment. "Yes, yes. Exactly. The disabling effects, basically, of society," replies Taylor (I95). In other words, the ways that she is able to move through space differently, by pulling herself forward on the ground with her arms, or how she requires level terrain for her mobility device, or how she can carry out functions with different body parts (mouth instead of hand, for instance) are scorned by society. And this, she concludes, is how society creates disability from impairment. Muckles must hear with his ears, as others do, rather than in myriad ways he navigated the world prior to his cochlear implant.

The young performers' anger over the failure of the audience to perceive the value of their story follows from their affective impulse to get Muckles's story right, to reproduce a comfort narrative which reinforces normalcy, to make people feel. The emotional effect and lure of Muckles's particular narrative - the conquest over disability - was what the students wished to communicate to an audience. As Paul, one of the group members, described, "I thought [the story] was remarkable and I wanted the feeling that I got when [Muckles] first told it to come across to the audience" (emphasis original, Focus Group Interview I6 
December 2015). It was a story, then, of big feeling, a feeling-knowing story that was seeking confirmation. This impulse was not perceptible to its audience, laughing aloud at points, because the stage naturalism verged on comical in its strict adherence to "real life" and its staged emotions. For instance, the parents - played by Muckles's peers - put on airs of adult concern when speaking to the doctor and nurse (also teenage actors) who themselves spoke unnaturally, like scientists lacking human compassion. The father "wept" at the sight of his son hearing his name for the first time but couldn't quite hit the mark of sentiment they were after. It was somewhere between melodrama and play-acting, all decidedly in an effort to remain true to the "real" story as narrated to them by Muckles. And given the aim for the piece to be about five minutes, the emotions were condensed and there seemed to be no time to develop the characters or their relationships to each other. As a consequence of all the adherence to the "facts" as recounted, the feeling-truth was lost. As Erin Hurley summarizes in Theatres of Affect:

Theatre is an intensely relational space [...] that makes the experiences it offers so potentially impressive and so very disappointing when they fail [...] theatre is a realm that tends to fuel desires of all kinds. (II)

Muckles and his classmates have not come to understandings of the politics of disability in the same way as they have not yet come to understand theatre as a political instrument rather than a transmitter of received social narratives that feel true. Performance theorist Dwight Conquergood maintains that marginalized people need spaces “for 'public discussion' of vital issues central to their communities, as well an arena for gaining visibility and staging their identity" (360). We think this may be an impulse that the young people in Muckles's group were indeed responding to, attuned as they are, as a diverse group of young people, to multiple forms of social stigmatization. But the pull of normative, narrative truth was very strong and the exploratory guidance that may have helped to question received truths and allow them to experiment aesthetically was unwelcome. In the absence of probing questions, the young people fell to auto/biographical narrative in its most narrow terms. Embodying the "real life" people, they became "dependent" as Jenn Stephenson describes, "on performative auto/biography" and that "narratively constituted fictive self [became] especially vulnerable to erosion and erasure through memory loss and narrative disability" (24) and, we would add in this case, the social organization of disability itself.

\section{Section 3. Resisting Real Failure: Doing it the Right Way(s) \\ University theatre studies students work with verbatim and oral history performance}

SUPERJET (as translated by Fei-fei): He said, the importance about the process is he can learn from mistakes. And through the process, he can gradually find his goal. And, people have to be used to making mistakes. But cannot give up.

DIRK (research assistant): Do you think that the world allows people to make mistakes? Do you think life allows people to make mistakes? 
SUPERJET (as translated by Fei-fei): In rehearsal, it's okay.

[...]

SUPERJET (as translated by Fei-fei): He said that in our life, actually failure is not acceptable.

But he, through drama, he finally realized that mistakes can be accepted.

(Focus Group Interview I6 November 2016)

After visiting our site in Tainan, Taiwan in November 2016, it became clear that among the many resonances with our Toronto site, there was a unique creative compulsion in Taiwan. The slightly older students of our Taiwan site - in university, living alone, and thinking very clearly about their families and futures-exhibited a distinct desire to tell the real in the theatrically "right" way. In our time with the students, under the direction of their professor, our collaborator Dr. Wan-Jung Wang, we watched a performance, attended rehearsals of upcoming devised pieces based on personal stories, and conducted interviews with students. Many of those students, like SuperJet above, described notions of failure, success, responsibility, and reality as parts of their creative process.

In their introductory editorial to an issue of Performance Research on failure, Róisín O'Gorman and Margaret Werry note how several authors have recently written to "recuperate failure, even champion it as a site of resistance. For them, failure's promise lies in its capacity to unravel the certainties of knowledge, competence, representation, normativity and authority" (I). Sara Jane Bailes agrees, writing that "in its status as 'wrongdoing,' a failed objective establishes an aperture, an opening onto several (and often many) other ways of doing that counter the authority of a singular or 'correct' outcome" (3). The suggestion is made that failure is potentially generative: it can be a tool for making visible the failures of representation in theatre, or it can be a marker of realness, risk, or authenticity as in the use of non-actors who may fail to perform at a professional standard. Indeed, failure can be positively connected to ideas of resistance, undermining, or anti-authority more generally; this argument has already been expanded upon in our earlier consideration of the productive disruption of the poltergeist, and also in our examination of the potential benefits of a disruption of representations of perceived normativity.

When we began a search for texts on performance and failure, following our initial analyses of our data, the first result returned was a book entitled Failure is Not an Option: Six Principles That Guide Student Achievement in High-Performing Schools, which has been cited 699 times to date according to Google Scholar. Indeed, O'Gorman and Werry argue that despite the necessity and embracing of failure within theatre practice, there remains a general resistance to or incompatibility between productive failure and education. In education, the rhetorical or discursive qualities assigned to the language of failure override any potentially positive practical experience: "this scene of teaching and learning, rather than the experimental space of performance art with its privileged freedom to fail, bring into sharp relief the stakes, economies and politics of failure" (O'Gorman and Werry I). This description is notably similar to SuperJet's articulation of failure in the real world versus the rehearsal hall quoted earlier. Indeed, when evaluation, grading, and even future job prospects and financial realities come into focus, failure becomes extremely unattractive; the realities of the world subsume any potential benefit failure may pose within the protection of the rehearsal hall. Chris Hay sums up the "bind" of creative arts teachers who are "on the one hand recognizing 
the necessity of failure in their pedagogy, but on the other working within a system that lionises success" (79).

It is important to turn our focus particularly to the documentary practices at work within the pedagogy of our project. Failure, or fear of failure, seems a prevalent presence in these genres that utilize some form of material from the real world: concern with performing ethically, accurately, and truthfully manifest in explorations of verbatim, documentary, and autobiographical plays. While not perhaps tied to grades, the students did articulate a fear of failing to accurately or adequately stage reality. As already noted in the Toronto students' work in oral history, for the Tainan students the challenges of staging reality prompted concern about "doing it right." Our collaborator, for instance, translated for one of the students, Xiao-Yi:

In the very beginning of the devising process, they kept bumping into the wall, because they worried they would fail the original story. Not like the original story. They kept bumping and blaming themselves. "It's not right!" (Focus Group Interview I6 November 2016)

Xiao-Yi was describing the process of attempting to perform her classmate Yuan-Yuan's personal story. Another student, Shuan-Shuan, went on to describe the pressures she felt, trying to act as Yuan-Yuan's mother:

[...] she was very pressured at the very beginning because she's going to play her mother, and she was so frightened that she might play the wrong impression of her mother and not doing it good enough. (Focus Group Interview I6 November 2016)

The very realness of what they were attempting to perform implied that there was a "wrong" way to do things.

A consideration of what forms of failure are present for students when they are asked to stage a piece of reality within an educational system reveals the even more closely intertwined paradox of failure as both a positive form of theatrical experimentation and as a debilitating and dangerous reality. Students are, arguably, left with the same absence of freedom to fail within pedagogy that O'Gorman and Werry describe, in this case manifest not only because of the constraints of the education system, but also because reality is used as theatrical fodder: students are left asking, does this artwork adequately or accurately convey what really happened? The demands of staging reality, with its ethical, efficacious import make it both a useful, powerful tool in pedagogy, but as illustrated can also prompt debilitating effects of being or feeling paralyzed by risk of failing to authentically, truthfully, or really stage reality. There is almost, then, a meta-failure spectre haunting the students, in ways perhaps similar to our earlier consideration of a ghostly spectre bound to reproduce the status quo; we are asking students, in a setting that is fundamentally failure-averse, to stage something that also prompts a fear of failure ethically. In other words, students might ask, "Will I receive a failing grade because I have failed to accurately represent the real?" Indeed, within this apparently high-stakes setting, documentary practices may actually set students up to fail. However, this may be a productive opportunity. 
Bailes writes that "Failure challenges $[. .$.$] the fictions of continuity that bind the way we$ imagine and manufacture the world [...] failure is inclusive, permissive even" (2). Indeed, it was the inevitability of failure that made staging a very real topic for the Taiwanese students possible. As our collaborator continued to describe, after releasing themselves from the necessity of doing things accurately, "they set themselves free" and "felt liberated" (Focus Group Interview I6 November 20I6). We also interviewed a class of students currently taking another course taught by our collaborator. The students had travelled to an indigenous village to learn of the ways in which the village was recovering following a natural disaster, then staged a performance called See You Again Kobayashi Village that dramatized life in the village including the residents' traditional songs, dances, and cultural practices:

WAN-JUNG (collaborator, translating): We felt that since we have all known about the disaster and the kind of sorrows they have been through in that disaster, or after the disaster, so we felt especially responsible to tell their stories with a strong sense of responsibility for the community members who have shared their sorrowful stories and how they passed through that painful process. And also when they come to see our show in the rehearsal they said how moved and happy they saw our show [. . . Although we are not so good at that in our performance, they are still so happy and moved. That's why we have to have this sense of responsibility to their stories, and tell it well, tell it better each time.

Failure in this way was arguably liberating for the students. They knew they might not perform it "well" but this did not temper their determination that it would be the responsible thing to do. Indeed, following Halberstam's The 2ueer Art of Failure, failing "may in fact offer more creative, more cooperative, more surprising ways of being in the world" (2-3), and actually encourage multi-directionality, contingency, and over-shooting. "Such notions of failure do not contradict hope and aspiration, but rather nurture them" (Harris 23) and indeed, the students seemed to feel more hopeful after their less-than-ideal attempt at staging the indigenous community. In the performance we saw, tempered by our own failures in communication inherent in watching a show performed entirely in languages we did not speak about a culture we did not know, there were markers that would suggest performance failure: one of the students did not quite know the dance steps, and the actors were out of breath at times. This did not affect, however, their earnest story-telling, motivated by their own kind of feeling-knowing to share what they knew was an important true story.

To add a further, somewhat complicating, notion to the discussion of productive failure, it is important to consider the specific aesthetic form of the student productions that we witnessed. This is where the plural notion of "failures" comes from: there may be several ways to fail to stage reality "right." Relieved from the duty to accurately convey reality, as suggested by the above interview excerpts, the groups appeared to invent a new standard of failure for themselves:

WAN-JUNG (collaborator, translating for Xiao-Li): Yuan-Yuan shared that she doesn't care if they present the original story of hers at all, just as long as they can convey the moving feelings that they felt in her story, because there are three characters, three actors want to play the main character in the story, and they must feel something about the story. She wants that 
part, that feelings get across to the audience. That's the most important thing. (Focus Group Interview I6 November 20I6)

The new aim or goal was to heighten the emotional experience of the spectators, similar in nature to the desires articulated by Toronto students. The students in Tainan actually attempted to "correct reality" and change social opinion. One of the other student groups created a play called Same, based on the experience of one of their group members coming out as gay. They decided to alter the ending of the real-life story to end with suicide and thus, they felt, it would be more emotionally impactful, even though this was not truthful to the reality: "the presentation can lead the audience to reflect on themselves and let them ask 'How can they make it better?'” (Focus Group Interview I6 November 2016). The attempt now was to communicate the buman truth in the right way, rather than communicate the factual story the right way. Or, arguably, to communicate the specific feeling-knowing of this group of creators, who felt strongly about intervening in society's perceived lack of care for the struggles of LGBTQ people. This sentiment was echoed across the student groups:

\begin{abstract}
WAN-JUNG (collaborator): Sian has shared that the fictional side of the oral history often intensified the dramatic tension, make it more dramatic and strengthening the issues and inner feelings of what they are going to discuss, than the original story.
\end{abstract}

KATHLEEN (researcher): Fiction makes it more real.

WAN-JUNG (collaborator): Yes, something like that. We have been sharing, we are trying to reveal the truth in human nature not the factual facts. (Focus Group I7 November 2016)

We cannot make the case as to whether this attempt to tell the perceived truth was ultimately one that the students felt was successful, as our time in Taiwan ended before their public performances, and, ultimately, these notions of success are likely unhelpful. What we offer instead is that these brief examples of three documentary-based performance pieces point to a necessary re-negotiation of the place of failure within pedagogies of documentary theatre-making. In efforts to produce theatre that is "true-to-life," failure is, as Bailes suggests, inevitable, and actually is what allows for and prompts the creative experience: it was liberating, to use Yuan-Yuan's words, in the performance of her family's story. There remains, however, the danger of still feeling compelled to perform the real the "right" way, even if freed from the measures of true-to-lifeness, as in the students' performance of Same through which they wished to have a real corrective effect on society. Theatre of the real, Carol Martin argues, can easily fall into the same closed system that theatrical realism might:

Typically [documentary theatre's] texts and performances are presented not just as a version of what happened but the version of what happened. The intention is to persuade spectators to understand specific events in particular ways. (II)

It is thus important to resist the totalizing impulse that seems to haunt documentary theatre practice, and rather to recognize and renegotiate notions of any singular "right" way and accept the inevitability of failure: as SuperJet articulated at the outset of this section, in 
attempting to represent reality, "mistakes can be accepted." Each choice made in the performance process will be both productive and limiting, and the question becomes not which method is the right way of reproducing reality, but rather which method does the work that the students feel the art needs to do.

\section{Concluding Thoughts}

As we noted at the beginning of this article, Radical Hope has been a project committed to examining how the processes of theatre-making furnish youth with unique opportunities to deepen their capacity for engagement, ethical action, creativity, and relationality with their many-faceted communities. When that theatre-making takes up documentary practices, when students aim to hear, analyze, and depict reality, one of the most persistent outcomes of the work is the need to contend with pedagogical, aesthetic, and relational failure. In some cases, as Sara Jane Bailes forecasts and as we observed in the Eric Harris docudrama, those stumblings manifest themselves as moments of Superjet's “acceptable mistakes" that are falling forward toward possibility, then creativity, and finally new apertures for their selfother relationships. But we also have witnessed less helpful forms of failure. When students have been captured by the well-intended desire to engage and stage in the "right way," they are prone to fall back into patterns of reflecting the normative able-ness of the powerful and majoritarian that we saw in Muckles's narrative (Butler; Ferri; Furlong). Such instances are especially unfortunate given that the roots of documentary are immersed in the desire to make visible those who have been typically invisible (Anderson and Wilkinson). More insidious, though, is the ubiquitous disposition toward conflating factual accuracy with "the real." This seductive paradigm has been appealing for the students we have encountered because it allowed for quick processing under persistently short time constraints, it seemed to match the tidy or "correct" product typically required by the educational system (i.e. replication) (O'Gorman and Werry), and it offered short-term, comforting narratives about the stability of their world (e.g. the reliability of the justice system, positive response to good-intentions). But as we have learned from the youth, a persistent dependence on the accuracy of one's personal feeling-knowing, Jenn Stephenson's "narratively constituted fictive self" (24), leaves a person dangerously unprepared for a more complex world filled with relationships and audiences who do not share their same social memories and values.

Far better, in our estimation, are those drama spaces where students are encouraged to knowingly embrace an unfettered praxis of failure. To avoid creatively closed systems (Hays; Martin), we might first draw from Bergson's deliberate troubling of the sense of immediacy and certainty. This includes challenging what it means for a student to meet a performance deadline and how tidy and unified their theatrical performances should ultimately be. We would also invite teachers and facilitators to build environments that make positive use of the "intensely relational space" that is evoked by theatre (Hurley II) in order to harness the power of collective inquiry, to demonstrate the danger and folly of individual certainty, and to mediate the inevitable anxiety brought about by the disruption of one's feeling-knowing. This ethos of jointly re-imaging and re-inventing continuity (Bailes; Powell) is easier to incite when, as in the first Toronto classroom, students can see their own erasure in the stories they hear and perform. Educators must be more vigilant, however, in making use of critical 
community when, as in the second Toronto classroom, students perceive they are recognizing more familiar narratives. This task of disruptive mindfulness might be made easier, we would suggest, when youth understand that drama at its best is and has always been a deeply political and "public discussion" (Conquergood 360). Citizens come together, not to represent factual realism, but to disrupt and queer the seemingly natural, in order to discover more profound, complex, and provisional human truths (Halberstam; Lather). We finally acknowledge that theatre that foregrounds the political may be initially dismissed as a tediously didactic affair (more so by traditional educators than students in our experience), "minus" the affective import that will draw in an audience (Deleuze 63). We counter by suggesting that by walking along with caring, hopeful, and politically astute students of drama, from Toronto to Tainan, we are discovering that it is the faithful betrayals, disrupted replicas, and haunted representations that most effectively convey messages that truly matter to youth. Might it be, in a world fearful of Machiavellian "alternative facts" and faux-authenticities, that part of the way forward is the mobilization of real and ethical fictions?

\section{Notes}

I In each of the three years of our study a different collaborator has led the practice to be carried out in all sites. In year one, our Toronto artist collaborator Andrew Kushnir (creative director of Project: Humanity) led our verbatim practice, in year two our collaborator Dr. Wan-Jung Wang of Taiwan led our oral history performance, and in year three our collaborator in Greece, Dr. Myrto Pigou-Repousi and artist Nikos Govas and our collaborator Dr. Rachel King at Warwick University with artist-practitioner Jouvan Fuccini from the Belgrade Theatre, led our devising and ensemble practice. Our collaborator Dr. Urvashi Sahni in Lucknow, India led us in a feminist dialogic practice she calls "critical dialogues," which is a practice of movement between scene development and critical analysis in a creative process. For an introduction to the international collaborators, see http://www.oise.utoronto.ca/dr/Research_Projects/Youth_Theatre_ Radical_Hope_and_the_Ethical_Imaginary/index.html.

2 The names of places and people are pseudonyms, chosen by our youth participants, except for the name of our research collaborator in Tainan. Further, any social identity markers used have also been chosen by our youth participants.

3 This video is available in a number of locations on the internet and edited to a variety of lengths.

4 In a previous publication in TRIC/TRAC, Gallagher wrote about the ways in which performances of qualitative research might be productively understood as respectful forgeries and faithful betrayals. See Gallagher, "Theatre Pedagogy.”

\section{Works Cited}

Agencies. "Video shows Tulsa police killing man using gun instead of Taser 'by mistake." Guardian, I5 April 2015. Web. May 2017.

Anderson, Michael and Linden Wilkinson. "A Resurgence of verbatim Theatre: Authenticity,

Empathy and Transformation." Australasian Drama Studies 50 (2007): 153-69. Print.

Aston, Elaine. An Introduction to Feminism and Theatre. London: Routledge, 2003. Print.

Bailes, Sara Jane. Performance Theatre and the Poetics of Failure. New York: Taylor \& Francis, 20IO. Print. 
Barker, Howard. "On Naturalism and its Pretensions." Studies in Theatre and Performance 27.3 (2007): 289-93. Print.

Barker, Roberta and Kim Solga, eds. Nerw Canadian Realisms: Nerw Essays on Canadian Theatre, Volume 2. Toronto: Playwrights Canada Press, 2012. Print.

Bergson, Henri. Matter and Memory. Trans. Nancy Margaret Paul and W. Scott Palmer. Cambridge: Zone Books, 1991. Print.

Blankstein, Alan. Failure is Not an Option: Six Principles that Guide Student Achievement in HighPerforming Schools. Thousand Oaks: Corwin Press, 2014. Print.

Butler, Judith. "Judith Butler with Sunara Taylor: Interdependence." Examined Life: Excursions with Contemporary Thinkers. Ed. Astra Taylor. New York: The New Press, 2009. Print.

Conquergood, Dwight. "Rethinking Ethnography: Towards a Critical Cultural Politics." The Sage Handbook of Performance Studies. Ed. D. Soyini Madison and Judith Hamera. Los Angeles: Sage Publishing, 2006. 347-50. Print.

Davis, L. J. "Constructing Normalcy: the Bell Curve, the Novel, and the Invention of the Disabled Body.” The Disability Studies Reader. $2^{\text {nd }}$ ed. Ed.L.J. Davis. New York: Routledge, 2006. 3-16. Print.

Deleuze, Gilles. Cinema I: The Movement-Image. Trans. Hugh Tomlinson and Barbara Habberjam. Minneapolis: U of Minnesosta Press, 1986. Print.

Dillon, Stephen and Allison Page. "The Haunting of Evidence." Cultural Studies-Critical Methodologies 15.4 (2015): 283-86. Print.

Field, Corinne T. "Why Little Thinkers are a Big Deal: The Relevance of Childhood Studies to Intellectual History.” Modern Intellectual History I4. I (20I7): 269-80. Print.

Ferri, Beth A. “(Dis)ability.” Keywords in Youth Studies: Tracing Affects, Movements, Knowledges. Ed.

Nancy Lesko and Susan Talburt. New York: Routledge, 2012. 29-34. Print.

Furlong, Andy. Youth Studies: an Introduction. New York: Routledge, 2013. Print.

Gallagher, Kathleen. "Theatre Pedagogy and Performed Research: Respectful Forgeries and Faithful Betrayals." Theatre Research in Canada/Recherches théatrales au Canada 28.2 (2008): 105-19. Print.

-. Why Theatre Matters: Urban Youth, Engagement, and a Pedagogy of the Real. Toronto: U of T Press, 20I4. Print.

Gallagher, Kathleen and Kelsey Jacobson. "Beyond Mimesis to an Assemblage of Reals in the Drama Classroom: Which Reals? Which Representational Aesthetics? What Theatre-Building Practices? Whose Truths?" Research in Drama Education: A Journal of Applied Theatre and Performance 23.I (2018): 40-55. Print.

"Ghost Stories." The Oxford Companion to English Literature. Ed. Dinah Birch. Oxford: Oxford UP, 2009. N.p. Web. 22 May 2017.

Halberstam, Jack. The 2ueer Art of Failure. Durham: Duke UP, 20II. Print.

Haley, Alex. "Black History, Oral History, and Genealogy." The Oral History Review I (I973): I-25. Print.

Harris, Anne M. The Creative Turn: Toward a New Aesthetic Imaginary. Boston: Sense Publishers, 2014. Print.

Hay, Chris. Knowledge, Creativity and Failure: A New Pedagogical Framework for Creative Arts. Basingstoke: Palgrave Macmillan, 20I6. Print.

Hurley, Erin, ed. Theatres of Affect: Nere Essays on Canadian Theatre, Volume 4. Toronto: Playwrights Canada Press, 20I4. Print. 
Jones, Corey. "Video of struggle, shooting is released." Tulsa World, ir April 2015. Web. I6 May 2017. Lather, Patti. "Fertile Obsession: Validity after Poststructuralism.” The Sociological 2uarterly 344 (1993): 673-93. Print.

Martin, Carol. "Bodies of Evidence." The Drama Review 50.3 (2006): 8-15. Print.

O'Gorman, Róisín, and Margaret Werry. "On Failure (On Pedagogy): Editorial Introduction." Performance Research I7.I (2012): I-8. Print.

O’Toole, John. "Writing Everyday Theatre: Applied Theatre, or just TIE Rides Again?" Research in Drama Education: The fournal of Applied Theatre and Performance I4.4 (Nov. 2009): 479-50I. Print.

Paget, Derek. "'verbatim Theatre': Oral History and Documentary Techniques." Nerw Theatre 2uarterly 3.12 (1987): 317-36. Print.

Powell, Kashif Jerome. "Making \#BlackLivesMatter: Michael Brown, Eric Garner, and the Specters of Black Life-Toward a Hauntology of Blackness." Cultural Studies-Critical Methodologies 16.3 (2016): 253-6o. Print.

Stephenson, Jenn. Performing Autobiography: Contemporary Canadian Drama. Toronto: U of T Press, 2013. 